\title{
Portuguese Inguinal Hernia Cohort (PINE) study
}

\section{Abstract}

Purpose: Recent comprehensive guidelines have been published on the management of inguinal hernia. Contrary to other European countries, no Portuguese hernia registry exists. This represents an opportunity to assess outcomes of hernia surgery in the Portuguese population. The primary aim is to define the prevalence of chronic pain after elective inguinal hernia repair. The secondary aims are to identify risk factors for chronic pain after elective inguinal hernia repair, to characterise the management of elective inguinal hernia in public Portuguese hospitals.

Methods: Prospective national cohort study of patients submitted to elective inguinal hernia repair. The primary outcome is the prevalence of chronic postoperative inguinal pain, according to the EuraHS QoL questionnaire at 3 months postoperatively. The study will be delivered in all Portuguese regions through a collaborative research network. Four 2-week inclusion periods will be open for recruitment. A site-specific questionnaire will capture procedure volume and logistical facilities for hernia surgery.

Conclusion: This protocol describes the methodology of a prospective cohort study on the elective management of inguinal hernia. It discusses key challenges and describes how the results will impact future investigation. The study will be conducted across a nationwide collaborative research network, with prospective quality assurance and data validation strategies. It will provide the basis for a more accurate prediction of chronic postoperative inguinal pain and the research on adequate patient selection strategies for surgery and therapeutic strategies for postoperative pain.

Keywords: inguinal hernia, chronic pain, general surgery, cohort study

Collaborative authorship: PT Surg

PT Surg - Portuguese Surgical Research Collaborative

Email: info@ptsurg.org

Twitter handle: @pt_surg

Steering Committee: J Simões ${ }^{1,2}$, AA João ${ }^{1,3}$, JM Azevedo ${ }^{1,4}$, M Peyroteo $^{1,5}$, M Cunha $^{1,6}$, B Vieira ${ }^{1,7}, \mathrm{~N}$ Gonçalves $^{1,8}$, J Costa ${ }^{1,8}$, AS Soares ${ }^{1,3}$ (corresponding author, +351963864555 )

Local Leads: JS Pimenta ${ }^{9}$, M Romano ${ }^{10}$, AM Cinza $^{11}$, I Miguel ${ }^{6}$, AR Martins ${ }^{3}$, G Fialho ${ }^{12}$, M Reia $^{13}$, FC Borges $^{2}$, CF Monteiro ${ }^{14}$, AC Soares ${ }^{7}$, P Sousa ${ }^{15}$, S Frade ${ }^{16}$, L Matos $^{17}$, JM Carvas ${ }^{18}$, SF Martins ${ }^{19}$, X


Parreira $^{26}$, P Santos ${ }^{27}$, F Caires ${ }^{28}$, A Torre ${ }^{29}$, SC Rodrigues ${ }^{30}$, AH Guimarães ${ }^{31}$, MF Carvalho ${ }^{32}$, MA NOTE: This preprint reports new research that has not been certified by peer review and should not be used to guide clinical practice. 
medRxiv preprint doi: https://doi.org/10.1101/2020.12.19.20247585; this version posted December 24, 2020. The copyright holder for this preprint (which was not certified by peer review) is the author/funder, who has granted medRxiv a license to display the preprint in It is made available under a CC-BY-ND 4.0 International license .

PINE protocol V1.0

Affiliation:

1- PT Surg - Portuguese Surgical Research Collaborative

2- Hospital Garcia de Horta

3- Hospital Professor Doutor Fernando Fonseca

4- Hospital da Horta

5- Instituto Português de Oncologia - Porto

6- Centro Hospitalar Universitário do Algarve - Portimão

7- Hospital do Santo Espírito da Ilha Terceira

8- Faculdade de Medicina da Universidade de Lisboa, Laboratório de Farmacologia Clínica e Terapêutica.

9- Unidade Local de Saúde Baixo Alentejo

10- Unidade Local de Saúde Castelo Branco

11- Hospital do Espirito Santo

12- Hospital de Portalegre

13- Hospital de Elvas

14- Unidade Local de Saúde do Alto Minho

15- Hospital Particular do Algarve

16- Centro Hospitalar Universitário de Lisboa Central

17- Centro Hospitalar de Entre o Douro e Vouga

18- Unidade Local de Saúde do Nordeste

19- Hospital Distrital de Santarém

20- Centro Hospitalar de Setúbal

21- Centro Hospitalar de Lisboa Ocidental - Hospital São Francisco Xavier

22- Centro Hospitalar de Lisboa Ocidental - Hospital Egas-Moniz

23- Centro Hospitalar de Lisboa Ocidental - Hospital de Santa Cruz

24- Hospital Pedro Hispano

25- Hospital Distrital da Figueira da Foz

26- Hospital do Divino Espirito Santo - Ponta Delgada

27- Centro Hospitalar do Oeste - Hospital de Torres Vedras

28- Centro Hospitalar do Oeste - Hospital das Caldas da Rainha

29- Hospital de Gaia

30- Hospital de São João

31- Centro Hospitalar Universitário de Coimbra

32- Hospital de Famalicão

33- Hospital de Aveiro

34- Unidade Local de Saúde do Litoral Alentejano

35- Centro Hospitalar de Lisboa Norte

36- Hospital Beatriz Ângelo

37- Hospital Cova da Beira

The members of PT Surg report no conflict of interests.

Acknowledgements: We thank our expert advisory panel (A de Beaux, E Guerreiro, F Ferreira, H FriisAndersen, M Rosen, N Henriksen, S Morales-Conde, T Bisgaard) for critical review of the protocol and constructive feedback. We thank our patient advisory panel (A Rocha, J Fonseca) for critical review of the data collection variables, schedule feasibility and outcomes. 
medRxiv preprint doi: https://doi.org/10.1101/2020.12.19.20247585; this version posted December 24, 2020. The copyright holder for this preprint (which was not certified by peer review) is the author/funder, who has granted medRxiv a license to display the preprint in It is made available under a CC-BY-ND 4.0 International license .

PINE protocol V1.0

\section{Introduction}

The lifetime risk of developing an inguinal hernia is $3-6 \%$ for women and $27-43 \%$ for men ${ }^{1}$. Symptomatic patients usually undergo surgery, as well as most patients with minimal or no symptoms (approximately 70\% ultimately undergo surgery at 5 years ${ }^{2}$ ). Therefore, surgical repair of inguinal hernia is one of the most common procedures performed by general surgeons worldwide. The development of chronic pain after inguinal hernia repair can lead to severe impairment of patient quality of life and may require re-intervention in a minority of cases. The mechanisms of chronic pain and risk factors are similar for all groin hernias and are often analysed together ${ }^{3}$. PINE will focus in groin hernia including both inguinal and femoral hernias. Chronic pain is commonly defined as pain lasting more than 3 months after hernia repair ${ }^{4,5}$ and is estimated to occur in $10-15 \%$ of patients after Lichtenstein hernia repair ${ }^{6,7}$. The prevalence of chronic pain after inguinal hernia repair in Portugal is unknown.

According to a survey conducted between 2001 and 2005, more than 9,000 surgical procedures for inguinal hernia were performed in Portuguese Public Hospitals ${ }^{8}$. Since then, there has not been an update on the management of inguinal hernia in Portugal. At present, there is no benchmark for the delivery of inguinal hernia surgery on a national level and there is no national hernia registry, as is the case in other countries ${ }^{9,10}$.

Given the high volume of inguinal hernia surgery, it is clinically relevant to define the current approach to inguinal hernia management in Portugal. The characterization of clinical practice variation could highlight the best management processes and allow their dissemination at a national level. From a Health System point of view, this could lead to important savings ${ }^{11}$ and care optimisation.

The recent publication of comprehensive guidelines on the management of inguinal hernia ${ }^{6}$, as well as the existence of national recommendations from the health governmental regulatory body "Direção Geral de Saúde" on antibiotic prophylaxis in the context of inguinal hernia repair, 
medRxiv preprint doi: https://doi.org/10.1101/2020.12.19.20247585; this version posted December 24, 2020. The copyright holder for this preprint (which was not certified by peer review) is the author/funder, who has granted medRxiv a license to display the preprint in It is made available under a CC-BY-ND 4.0 International license.

PINE protocol V1.0

offers us an opportunity to query the current practice in Portugal. We believe that this framework could provide actionable insight into such a fundamental area in general surgery.

The PINE study will be conducted by a trainee-led national network of surgical residents. The model for trainee-led research collaboratives was pioneered in the UK. ${ }^{12,13}$. These networks have proved successful in delivering major surgical research initiatives, including multicentre cohort studies and randomised controlled trials (RCTs) $)^{14}$. The Portuguese Surgical Research Collaborative (PT Surg) is a trainee led non-profit organisation, that aims to develop research in surgery, delivered by surgery residents and medical students. It was created to help a new generation of research active, nationally-linked surgeons, setting up a platform for collaboration both at national and international levels (https://twitter.com/pt surg \& www.ptsurg.org). PT Surg has already actively participated in other international studies ${ }^{15,16}$.

A national prospective multicentre cohort study will be conducted to define the risk factors for chronic pain after elective inguinal hernia repair in Portuguese hospitals and will identify current management options.

\section{Aims}

Primary objective: to define the prevalence of chronic pain after inguinal hernia surgery.

Secondary objectives: to identify risk factors for chronic pain after elective inguinal hernia repair, to characterise the management of elective inguinal hernia in public Portuguese hospitals. 
medRxiv preprint doi: https://doi.org/10.1101/2020.12.19.20247585; this version posted December 24, 2020. The copyright holder for this preprint (which was not certified by peer review) is the author/funder, who has granted medRxiv a license to display the preprint in It is made available under a CC-BY-ND 4.0 International license.

PINE protocol V1.0

\section{Methods}

\section{Study Design}

Prospective multicentre cohort study. Patient data will be collected at index admission, 30 days, 3 and 6 months after surgery (see fig. 1). This protocol follows the STROBE guidelines 17 and the STROCCS statement ${ }^{18}$. PINE study represents a phase $2 b$ study of the surgical innovation framework IDEAL ${ }^{19}$. PINE is registered at Clinicaltrials.gov with the reference NCT04328597.

\section{$\underline{\text { Patient selection }}$}

Inclusion criteria

- Consecutive patients over 18 years of age submitted to elective groin hernia repair in Portuguese Hospitals

- Willing and able to consent and comply with the follow up protocol

\section{$\underline{\text { Exclusion criteria }}$}

- Urgent/emergent inguinal hernia repair

Patients will be recruited by the clinical care team at each centre and identified through active search of schedules for elective surgeries. Participant centres will include hospitals of all levels of differentiation and means, ranging from district hospitals to tertiary referral centres. Prior to patient's enrolment, each centre will complete a survey describing the logistic conditions available, as well as some variables related to surgery volume (see supplementary table 1).

\section{Patient assessment and outcomes}

A member at each study centre will approach the patient during the index admission to explain the objectives of the study and the planned assessment schedule (see figure 1). At each 
medRxiv preprint doi: https://doi.org/10.1101/2020.12.19.20247585; this version posted December 24, 2020. The copyright holder for this preprint (which was not certified by peer review) is the author/funder, who has granted medRxiv a license to display the preprint in It is made available under a CC-BY-ND 4.0 International license.

PINE protocol V1.0

centre, in order to obtain ethical approval, additional items may be added to the protocol after revision by the committee. Informed consent will be obtained from all participants. It will be highlighted to the participant that informed consent can be withdrawn at any moment, as well as that there is no obligation to enter the study. The absence of any clinical consequence in case of withdrawal of the informed consent or refuse to participate in the study will also be highlighted to the patient.

At hospital admission, data will be collected on the patient's demographics, preoperative assessment (see supplementary table 1) and surgical approach (see supplementary table 2). Patients will be contacted by telephone to gather data on early postoperative period at $30( \pm 2)$ days after the index surgery (see supplementary table 3), if the first outpatient clinic appointment falls outside of this period. Data on the late postoperative period at 3 months ( \pm 1 week), 6 months ( \pm 1 week) after the index surgery (see supplementary table 4$)$ will also be assessed in the same way.

Patients will be considered lost to follow up for defined time periods if the study team cannot contact them after 3 attempts in 3 different days.

\section{Data management and quality assurance}

A team of collaborators will recruit patients in each specific period. Data will be collected and stored online through a secure server running the Research Electronic Data Capture (REDCap) web application. REDCap allows collaborators to enter and store data in a secure system. It is widely used by academic institutions throughout Europe and all storage of web-based information by this system is encrypted and compliant with HIPAA-Security Guidelines in the United States. One REDCap login will be issued per recruitment team.

All anonymous data will be held for a total of three years after study completion, after which it will be permanently removed from the server space. A unique 'REDCap ID' will be generated by the system for each patient. A local cross-reference of hospital numbers and 
medRxiv preprint doi: https://doi.org/10.1101/2020.12.19.20247585; this version posted December 24, 2020. The copyright holder for this preprint (which was not certified by peer review) is the author/funder, who has granted medRxiv a license to display the preprint in It is made available under a CC-BY-ND 4.0 International license .

PINE protocol V1.0

REDCap IDs should be kept in a secure, encrypted spreadsheet on an institutional passwordprotected computer. After obtaining the written informed consent from the patient, a contact phone number will be kept for further follow up according to the assessment plan (see figure 1). Paper data registries should be destroyed as confidential waste within the center, once uploaded to REDCap. This document should be deleted at the end of the follow-up period.

The local lead is responsible for securing the Ethics Committee approval at each hospital. Only hospitals with confirmed ethical approval will recruit patients.

\section{$\underline{\text { Data collection tools }}$}

Before starting patient recruitment, centre specific variables will be collected through a centre survey (see supplementary table 5).

Baseline and operative patient data will be collected through patient interview and admission record consultation. Inguinal hernias will be classified according to the European Hernia Classification $^{20}$.

After discharge, follow-up will be conducted through phone interviews at 1, 3- and 6months post-surgery, independently of planned clinic visits (except for the $1^{\text {st }}$ month, as previously explained).

Operative morbidity will be assessed according to the Clavien Dindo classification ${ }^{21}$. Surgical site infection will be defined according to the $\mathrm{CDC}$ criteria ${ }^{22}$ and additionally cases with antibiotic use for surgical site inflammatory signs with no overt pus drainage. If the patient is not able to confirm the occurrence of surgical site infection by phone, medical records and prescriptions will be retrieved from the individual health data platform (Plataforma de Dados de Saúde).

Chronic postoperative inguinal pain (CPIP) will be characterized from Patient Reported Outcomes (PRO) data. For this purpose, we will use the EuraHS-QoL score, Portuguese version, 
medRxiv preprint doi: https://doi.org/10.1101/2020.12.19.20247585; this version posted December 24, 2020. The copyright holder for this preprint (which was not certified by peer review) is the author/funder, who has granted medRxiv a license to display the preprint in It is made available under a CC-BY-ND 4.0 International license.

PINE protocol V1.0

developed by the Working Group of the European Registry for Abdominal Wall Hernias $(\text { EuraHS })^{23}$. The EuraHS-QoL questionnaire measures quality of life in patients undergoing abdominal wall hernia repair, with or without mesh implantation to repair the defect. It is employed both pre- and post-operatively. This PRO score is based on a Numerical Rating Scale for three dimensions:

1. pain at the site of the hernia or the hernia repair

2. restriction of activities

3. cosmetic discomfort

Patients will be asked to answer 9 questions comprising the dimensions above. As this questionnaire assesses other quality of life dimensions besides pain, we will be able to describe their variation over time. The score has been validated and EuraHS QoL pain domain was found to be strongly correlated to Visual Analogue Scale and Verbal Rating Scale ${ }^{23}$. The cutoff of 3/10 is the most used to define moderate/disturbing pain ${ }^{24-28}$ and is related to treatment request in such numeric rating scales ${ }^{29}$. Chronic postoperative inguinal pain will be defined as a score of $\geq 3 / 10$ on any of the question of the pain domain in the scale (during rest, during activity, in the last week) 3 months or more after surgery. Patient compliance in answering EuraHS-QoL will be assessed in our Patient and Public Involvement (PPI) exercise, including patients' ability to answer by phone.

\section{Data validation}

Following data collection, only data sets with $>90 \%$ data completeness will be accepted for pooled analysis. Centres with $>10 \%$ missing data points will not be included in the study or in scientific publications referring to this study. A validator will independently identify all patients eligible for inclusion over a 14-day study period. The target for case ascertainment is $>85 \%$ and certain key variables will be confirmed. 
medRxiv preprint doi: https://doi.org/10.1101/2020.12.19.20247585; this version posted December 24, 2020. The copyright holder for this preprint (which was not certified by peer review) is the author/funder, who has granted medRxiv a license to display the preprint in It is made available under a CC-BY-ND 4.0 International license .

PINE protocol V1.0

\section{$\underline{\text { Statistical considerations }}$}

We anticipate that over 25 centres will participate, each enrolling a minimum of 10 patients during the study period. A cohort of 500 patients would allow to estimate the prevalence of chronic pain after inguinal hernia management (assuming a prevalence of $15.2 \%)^{7}$, with $80 \%$ power, a significance level of $5 \%(\alpha=0.05)$ and a margin of error of $\pm 3 \%$.

The outcomes in relation to our primary objective (chronic pain after elective inguinal hernia repair) will be characterized through descriptive statistics. The outcomes in relation to our secondary objective (characterization of the elective management of groin hernia) will be analysed with descriptive statistics. Logistic regression will be applied to the data to identify risk factors for chronic pain after elective groin hernia repair. The following clinical factors were identified as potential risk factors:

- Age

- Gender

- Pre-operative inguinal pain

- Chronic pain from other cause

- Previous inguinal hernia repair

- Operative technique

- Mesh fixation method

- Nerve handling

- Peri-operative field block

- Immediate post-operative pain

- Post-operative complications (Clavien Dindo Classification)

- Inguinal sensitive symptoms

These factors will be studied prior to the logistic regression to identify its association with the presence of chronic pain after elective inguinal hernia repair through bivariate statistical analysis. 
medRxiv preprint doi: https://doi.org/10.1101/2020.12.19.20247585; this version posted December 24, 2020. The copyright holder for this preprint (which was not certified by peer review) is the author/funder, who has granted medRxiv a license to display the preprint in It is made available under a CC-BY-ND 4.0 International license.

PINE protocol V1.0

An interim analysis will be carried out after the 30-days follow-up assessment is completed for every patient included. No hypothesis testing will occur at this point. Patients lost to follow up, i.e. with missing data on the 3 months postoperative assessment, will not be included in the main analysis.

\section{PINE study organisational structure}

The study will be coordinated by PT Surg, which is the study promotor in collaboration with the Laboratory of Clinical Pharmacology and Therapeutics of the Lisbon School of Medicine. All Portuguese hospitals performing elective inguinal hernia repairs will be invited to participate. A core group of trainees will manage the study. At each centre, there will be a local lead, a supervising consultant and one team in each recruitment period. Each of these teams will have 3 elements, either trainees and/or medical students. Because we aim to promote the development of a national network for conducting clinical research in general surgery, our plan is to organise a course on research methodology to stimulate the scientific development of all the collaborators, therefore adding a benefit for participating in the study. A national and international representative expert advisory panel of surgeons dedicated to abdominal wall surgery has been consulted for the purpose of the developing this protocol and interpreting the findings. 
medRxiv preprint doi: https://doi.org/10.1101/2020.12.19.20247585; this version posted December 24, 2020. The copyright holder for this preprint (which was not certified by peer review) is the author/funder, who has granted medRxiv a license to display the preprint in It is made available under a CC-BY-ND 4.0 International license.

PINE protocol V1.0

\section{Patient and public involvement}

A selected group of patients has critically reviewed the data collection variables, schedule feasibility and outcomes. The relevance of the outcomes and feasibility of the proposed assessment schedule was discussed and deemed relevant and acceptable by the patients. The patients also agreed that there should be an option to collect their phone numbers. These results will be detailed in a posterior publication.

\section{Authorship policy}

Data collection team collaborators, consultant surgeons, data validators, local leads and the study management group are eligible for PubMed-citable co-authorship ${ }^{30}$. A maximum of three collaborators per data collection period will be listed as 'PubMed' citable authors. Validators at each site are also eligible for authorship. Centres with $>5 \%$ missing data will be excluded from the analysis and the contributing local team will be not be eligible for authorship. In line with the International Committee of Medical Journal Editors authorship guidelines, one consultant per centre is eligible for collaborative PubMed citable co-authorship providing that the following criteria are met: support of local study registration, circulate information about the study to consultant colleagues, and facilitate the presentation of local results at a departmental meeting. For an example of this authorship style, see PubMed with PMID: 29897171 
medRxiv preprint doi: https://doi.org/10.1101/2020.12.19.20247585; this version posted December 24, 2020. The copyright holder for this preprint (which was not certified by peer review) is the author/funder, who has granted medRxiv a license to display the preprint in It is made available under a CC-BY-ND 4.0 International license.

PINE protocol V1.0

\section{$\underline{\text { Study schedule }}$}

Based on previous projects developed with similar methodology, the planned schedule for the PINE study can be found on table 1 .

\section{Conclusions}

This protocol describes the methodology of a prospective cohort study on the elective management of inguinal hernia in Portuguese hospitals. It discusses key challenges and describes how the results will impact future investigation. The study will be conducted across a nationwide collaborative research network, with prospective quality assurance and data validation strategies.

It will provide the basis for a more accurate prediction of chronic postoperative inguinal pain as predictive factors for this postoperative adverse event will be studied. The study will also contribute to the research on adequate patient selection strategies for surgery and therapeutic strategies for postoperative pain. 
medRxiv preprint doi: https://doi.org/10.1101/2020.12.19.20247585; this version posted December 24, 2020. The copyright holder for this preprint (which was not certified by peer review) is the author/funder, who has granted medRxiv a license to display the preprint in

perpetuity.
It is made available under a CC-BY-ND 4.0 International license.

PINE protocol V1.0

\section{Acknowledgments}

We thank our expert advisory panel (A de Beaux, E Guerreiro, F Ferreira, F Muysoms, H FriisAndersen, M Rosen, N Henriksen, S Morales-Conde, T Bisgaard) for critical review of the protocol and constructive feedback.

We thank T Pinkney for helpful discussion on the methodology of this project.

We thank our patient advisory panel for critical review of the data collection variables, schedule feasibility and outcomes.

\section{References}

1. Kingsnorth, A. \& LeBlanc, K. Hernias: Inguinal and incisional. Lancet 362, 1561-1571 (2003).

2. Fitzgibbons, R. J. et al. Long-term results of a randomized controlled trial of a nonoperative strategy (watchful waiting) for men with minimally symptomatic inguinal hernias. Ann. Surg. 258, 508-514 (2013).

3. Reinpold, W. Risk factors of chronic pain after inguinal hernia repair: a systematic review. Innov. Surg. Sci. 2, 61-68 (2017).

4. Classification of chronic pain. Descriptions of chronic pain syndromes and definitions of pain terms. Prepared by the International Association for the Study of Pain, Subcommittee on Taxonomy. Pain. Suppl. 3, S1-226 (1986).

5. Aasvang, E. \& Kehlet, H. Chronic postoperative pain: the case of inguinal herniorrhaphy. Br. J. Anaesth. 95, 69-76 (2005).

6. Simons, M. P. et al. International guidelines for groin hernia management. Hernia doi:10.1007/s10029-017-1668-x

7. Lundström, K.-J., Holmberg, H., Montgomery, A. \& Nordin, P. Patient-reported rates of chronic pain and recurrence after groin hernia repair. Br. J. Surg. (2017). doi:10.1002/bjs.10652

8. Neto AJ, Magalhaes C, Domingues S, S. M. Abdominal Wall Hernias. Organize to Improve. Rev. Port. Cir. 15, (2010).

9. Friis-Andersen, H. \& Bisgaard, T. The Danish Inguinal Hernia database. Clin. Epidemiol. 8, 521524 (2016).

10. Köckerling, F. Data and outcome of inguinal hernia repair in hernia registers - a review of the literature. Innov. Surg. Sci. 2, 69-79 (2017).

11. Malik, H. T., Marti, J., Darzi, A. \& Mossialos, E. Savings from reducing low-value general surgical interventions. doi:10.1002/bjs.10719

12. Bhangu, A., Kolias, A. G., Pinkney, T., Hall, N. J. \& Fitzgerald, J. E. Surgical research collaboratives in the UK. Lancet 382, 1091-1092 (2013).

13. STARSurg Collaborative. Multicentre prospective cohort study of body mass index and postoperative complications following gastrointestinal surgery. Br. J. Surg. 103, 1157-1172 (2016).

14. DREAMS Trial Collaborators and West Midlands Research Collaborative, D. T. C. and W. M. R. Dexamethasone versus standard treatment for postoperative nausea and vomiting in gastrointestinal surgery: randomised controlled trial (DREAMS Trial). BMJ 357, j1455 (2017).

15. Group, R. S. Right Iliac Fossa Pain Treatment ( RIFT ) Study : protocol for an international, multicentre , prospective obsersdesdevational study. doi:10.1136/bmjopen-2017-017574

16. EuroSurg Collaborative. Ileus Management International (IMAGINE): Protocol for a multicentre, 
medRxiv preprint doi: https://doi.org/10.1101/2020.12.19.20247585; this version posted December 24, 2020. The copyright holder for this preprint (which was not certified by peer review) is the author/funder, who has granted medRxiv a license to display the preprint in

perpetuity.
It is made available under a CC-BY-ND 4.0 International license .

PINE protocol V1.0

observational study of ileus after colorectal surgery. Color. Dis. (2017). doi:10.1111/codi.13976

17. von Elm, E. et al. The Strengthening the Reporting of Observational Studies in Epidemiology (STROBE) Statement: guidelines for reporting observational studies. Int. J. Surg. 12, 1495-9 (2014).

18. Agha, R. et al. STROCSS 2019 Guideline: Strengthening the reporting of cohort studies in surgery. Int. J. Surg. 72, 156-165 (2019).

19. Hirst, A. et al. No Surgical Innovation Without Evaluation. Ann. Surg. XX, 1 (2018).

20. Miserez, M. et al. The European hernia society groin hernia classication: Simple and easy to remember. Hernia 11, 113-116 (2007).

21. Clavien PA, Barkun J, de Oliveira ML, Vauthey JN, Dindo D, Schulick RD, de Santibañes E, Pekolj J, Slankamenac K, Bassi C, Graf R, Vonlanthen R, Padbury R, Cameron JL, M. M. The Clavien-Dindo Classification of Surgical Complications Five Year Experience. Ann. Surg. 250, 187-196 (2009).

22. Berríos-Torres, S. I. et al. Centers for Disease Control and Prevention Guideline for the Prevention of Surgical Site Infection, 2017. JAMA Surg. 152, 784 (2017).

23. Muysoms, F. E. et al. A prospective, multicenter, observational study on quality of life after laparoscopic inguinal hernia repair with ProGrip laparoscopic, self-fixating mesh according to the European Registry for Abdominal Wall Hernias Quality of Life Instrument. Surg. (United States) 160, 1344-1357 (2016).

24. Loos, M. J. A., Houterman, S., Scheltinga, M. R. M. \& Roumen, R. M. H. Evaluating postherniorrhaphy groin pain: Visual Analogue or Verbal Rating Scale? Hernia 12, 147-151 (2008).

25. Rago, R. et al. Evaluation of a preoperative pain score in response to pressure as a marker of postoperative pain and drugs consumption in surgical thyroidectomy. Clin. J. Pain 28, 382-386 (2012).

26. Jönsson, A. C., Lindgren, I., Hallström, B., Norrving, B. \& Lindgren, A. Prevalence and intensity of pain after stroke: A population based study focusing on patients perspectives. J. Neurol. Neurosurg. Psychiatry 77, 590-595 (2006).

27. Jensen, M. P., Chen, C. \& Brugger, A. M. Interpretation of visual analog scale ratings and change scores: A reanalysis of two clinical trials of postoperative pain. J. Pain 4, 407-414 (2003).

28. Collins SL, Moore RA \& McQuay H. The visual analogue pain intensity scale:what is moderate pain in millimeters? Pain 72, 95-97 (1997).

29. Boogaerts, J. G., Vanacker, E., Seidel, L., Albert, A. \& Bardiau, F. M. Assessment of postoperative nausea using a visual analogue scale. Acta Anaesthesiol. Scand. 44, 470-474 (2000).

30. Blencowe, N. et al. Recognising contributions to work in research collaboratives: Guidelines for standardising reporting of authorship in collaborative research. Int. J. Surg. 52, 355-360 (2018). 


\section{Supplementary documents}

Supplementary table 1 - Demographic data and Surgical assessment.

\begin{tabular}{|c|c|c|c|}
\hline \multicolumn{2}{|r|}{ Variable name } & Options & Description \\
\hline \multirow{19}{*}{ 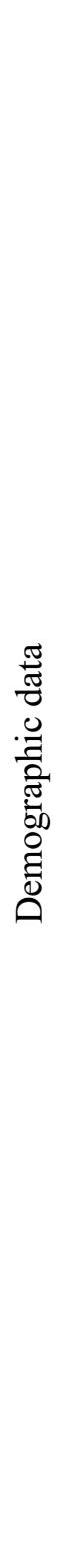 } & Age & & In years \\
\hline & Gender & & Male, Female \\
\hline & BMI & & Weight / Height squared \\
\hline & ASA grade & I, II, IIII, IV & \\
\hline & Smoking habits & Yes, No, Ceased & \\
\hline & Number of pack years & & $\begin{array}{c}\text { (packs smoked per day) }) \times(\text { years } \\
\text { as a smoker })\end{array}$ \\
\hline & $\begin{array}{l}\text { Family history of inguinal } \\
\text { hernia }\end{array}$ & Yes, No & \\
\hline & \multirow{5}{*}{ Comorbidities } & $\begin{array}{c}\text { Abnormal collagen } \\
\text { metabolism }\end{array}$ & \\
\hline & & Immunodepression & \\
\hline & & Pulmonary comorbidities & COPD, asthma \\
\hline & & Cardiovascular comorbidities & $\begin{array}{c}\text { Ischemic heart disease, } \\
\text { valvulopathy, congestive heart } \\
\text { failure }\end{array}$ \\
\hline & & Hepatic disease & Cirrhosis, ascites \\
\hline & $\begin{array}{l}\text { Chronic pain from other } \\
\text { cause (not the hernia) }\end{array}$ & $\begin{array}{l}\text { Headache, Inflammatory } \\
\text { osteoarticular disease, } \\
\text { Degenerative osteoarticular } \\
\text { disease, fibromyalgia, post- } \\
\text { traumatic pain, post-surgical } \\
\text { pain, cancer, nervous } \\
\text { injury/compression, other }\end{array}$ & \\
\hline & $\begin{array}{l}\text { Previous inguinal hernia } \\
\text { repair }\end{array}$ & Yes/No & \\
\hline & $\begin{array}{c}\text { Number of previous } \\
\text { surgeries }\end{array}$ & & \\
\hline & Site of previous repair & Ipsilateral, Contralateral & \\
\hline & Approach & $\begin{array}{l}\text { Anterior, posterior, laparo- } \\
\text { endoscopic }\end{array}$ & \\
\hline & Time since last surgery & & In months \\
\hline & Previous prostatectomy & Yes, No & \\
\hline \multirow{3}{*}{ 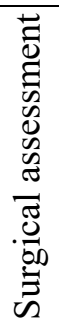 } & Indication for surgery & $\begin{array}{l}\text { Asymptomatic or Minimally } \\
\text { symptomatic; Symptomatic }\end{array}$ & $\begin{array}{c}\text { Symptomatic defined as painful, } \\
\text { emergency department } \\
\text { consultation, interference with } \\
\text { daily life }\end{array}$ \\
\hline & Preoperative imaging & Yes/No & \\
\hline & Type of imaging & $\begin{array}{l}\text { Ultrasound, CT, MRI, } \\
\text { herniography }\end{array}$ & \\
\hline
\end{tabular}


medRxiv preprint doi: https://doi.org/10.1101/2020.12.19.20247585; this version posted December 24, 2020. The copyright holder for this preprint (which was not certified by peer review) is the author/funder, who has granted medRxiv a license to display the preprint in perpetuity.

\section{Supplementary table 2 - Operative data variables.}

\begin{tabular}{|c|c|c|c|c|}
\hline \multicolumn{3}{|c|}{ Variable name } & Options & Description \\
\hline \multirow{12}{*}{ 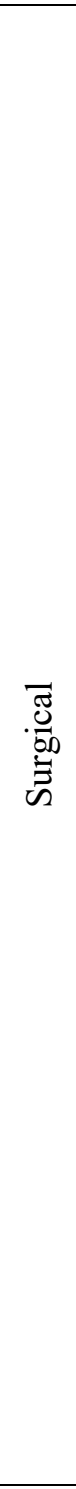 } & \multirow{3}{*}{\multicolumn{2}{|c|}{ Operative technique }} & Non mesh & Shouldice, Bassini, Desarda \\
\hline & & & Open mesh & $\begin{array}{c}\text { Lichtenstein, Trans inguinal } \\
\text { pre-peritoneal (TIPP), Trans } \\
\text { rectal pre-peritoneal (TREPP), } \\
\text { Plug and patch, PHS (bilayer), } \\
\text { Variations }\end{array}$ \\
\hline & & & Laparo-endoscopic & $\begin{array}{c}\text { Totally extraperitoneal (TEP), } \\
\text { Transabdominal preperitoneal } \\
\text { (TAPP), Single incision } \\
\text { laparoscopic repair (SILS), } \\
\text { robotic }\end{array}$ \\
\hline & & Conversion & Yes/No & \\
\hline & Mesh t & & Lightweight, Heavywight & $\begin{array}{c}\text { Heavyweight if }>80 \mathrm{~g} / \mathrm{m} 2, \\
\text { Lightweight if }<80 \mathrm{~g} / \mathrm{m} 2\end{array}$ \\
\hline & Fixation $n$ & ethod & $\begin{array}{l}\text { non-absorbable suture, slow absorbable } \\
\text { suture, quick absorbable suture, non- } \\
\text { absorbable tackers, absorbable tackers, } \\
\text { fibrin glue, other }\end{array}$ & \\
\hline & Hernia & & $\begin{array}{c}1=<1,5 \mathrm{~cm} \text { (one finger) } \\
2=<3 \mathrm{~cm} \text { (two fingers) } \\
3=>3 \mathrm{~cm} \text { ( }>2 \text { fingers) } \\
\mathrm{x}=\text { not investigated }\end{array}$ & \\
\hline & Level of ex & ertise & Trainee, Consultant & \\
\hline & Antibiotic pr & phylaxis & Yes, No & \\
\hline & & Drug & & \\
\hline & Hernya tipe & & Direct, indirect, femoral & \\
\hline & Nerve handling & & $\begin{array}{l}\text { Non-Identification, Identification, } \\
\text { Handling, Iatrogenic section }\end{array}$ & \\
\hline \multirow{3}{*}{ 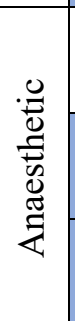 } & $\begin{array}{l}\text { Anaesthetic } \\
\text { technique }\end{array}$ & & $\begin{array}{l}\text { General anaesthetic, regional } \\
\text { anaesthetic, local anaesthetic }\end{array}$ & \\
\hline & $\begin{array}{l}\text { Perioperative } \\
\text { field block }\end{array}$ & & Yes, No & \\
\hline & & Type & $\begin{array}{l}\text { Ilio-inguinal, ilio-hypogastric, } \\
\text { subcutaneous, subfascial }\end{array}$ & \\
\hline
\end{tabular}


medRxiv preprint doi: https://doi.org/10.1101/2020.12.19.20247585; this version posted December 24, 2020. The copyright holder for this preprint (which was not certified by peer review) is the author/funder, who has granted medRxiv a license to display the preprint in perpetuity.

It is made available under a CC-BY-ND 4.0 International license

PINE protocol V1.0

Supplementary table 3 - Early (30 days) postoperative assessment data.

\begin{tabular}{|c|c|c|c|}
\hline \multicolumn{2}{|r|}{ Variable name } & Options & Description \\
\hline \multirow{5}{*}{ 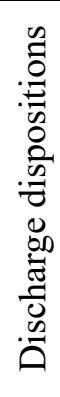 } & Discharge after surgery & $\begin{array}{l}\text { Same day, next day, } \\
\text { other }\end{array}$ & If other, specify number of days \\
\hline & Immediate post operative pain & $\begin{array}{c}\text { numerical grading scale } \\
(0-10)\end{array}$ & (maximum level during first week) \\
\hline & Post discharge analgesia & Opioid, NSAID, Other & specify other \\
\hline & Time to return to work & & Time to return to work (days) \\
\hline & $\begin{array}{l}\text { If hasn't returned specify } \\
\text { reason }\end{array}$ & & \\
\hline \multirow{2}{*}{ こ } & Inguinal sensitive symptoms & Parestesia, Anestesia & (in the operated inguinal region) \\
\hline & EuraHs QoL Score [22] & & $\begin{array}{l}\text { http://eurahs.eu/EuraHS-QoL- } \\
\text { download.php }\end{array}$ \\
\hline \multirow[t]{4}{*}{ 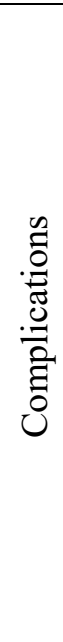 } & Surgical site infection [21] & Yes, No & $\begin{array}{l}\rightarrow \text { Purulent with or without } \\
\text { laboratory confirmation, from the } \\
\text { superficial incision } \\
\rightarrow \text { Organisms isolated from an } \\
\text { aseptically obtained culture of } \\
\text { fluid or tissue from the superficial } \\
\text { incision } \\
\rightarrow \geq 1 \text { signs/symptoms of infection: } \\
\text { pain, localized swelling, redness, } \\
\text { or heat } \\
\rightarrow \text { Diagnosis of SSI by the surgeon }\end{array}$ \\
\hline & Return to emergency department & Yes, No & \\
\hline & Hospital readmission & Yes, No & \\
\hline & Clavien dindo grade & I, II, III, IV & \\
\hline
\end{tabular}

Supplementary table $4-3$ - and 6-month postoperative assessment data

\begin{tabular}{|c|c|c|}
\hline Variable name & Options & Description \\
\hline Contact date & & Date \\
\hline EuraHs QoL Score [22] & & http://eurahs.eu/EuraHS-QoL-download.php \\
\hline Return to work after surgery & Yes, No & Time to return to work (days) \\
\hline Time & & \\
\hline Recurrence & Yes, No & \\
\hline
\end{tabular}


medRxiv preprint doi: https://doi.org/10.1101/2020.12.19.20247585; this version posted December 24, 2020. The copyright holder for this preprint (which was not certified by peer review) is the author/funder, who has granted medRxiv a license to display the preprint in perpetuity.

\section{Supplementary table 5 - Centre survey}

\begin{tabular}{|c|c|c|c|}
\hline \multicolumn{2}{|r|}{ Variable name } & Options & Description \\
\hline \multirow{5}{*}{$\begin{array}{l}\mathbf{E} \\
\Xi \\
0 \\
0 \\
0 \\
0 \\
0 \\
0\end{array}$} & Number of annual inguinal hernia repairs & & \\
\hline & Number of annual laparo-endoscopic repairs & & \\
\hline & $\begin{array}{c}\text { Number of surgeons performing inguinal hernia } \\
\text { repair }\end{array}$ & & \\
\hline & Complex inguinal hernia repair & Yes, No & $\begin{array}{l}\text { Surgery for multiple recurrences, } \\
\text { chronic pain, mesh infection }\end{array}$ \\
\hline & Number of annual procedures & & \\
\hline & Formal protocol defined & Yes, No & \\
\hline
\end{tabular}

\section{Suplementary Table 6 - PINE study schedule}

\begin{tabular}{|c|c|c|}
\hline Task & Duration & Predicted conclusion date \\
\hline Centre recruitment & 3 months & 4th October 2019 \\
\hline Local ethical approvals & 3 months & 4th October 2019 \\
\hline Patient recruitment & 3 periods & \\
\hline Period 1 & 2 weeks & 7-18 Oct 2019 \\
\hline period 2 & 2 weeks & 28th Oct -8 th Nov 2019 \\
\hline period 3 & 2 weeks & 18 - 29th Nov 2019 \\
\hline period 4 & 2 weeks & 2 - 14th Dec 2019 \\
\hline Interim analysis & 1 month & After 29th Dec 2019 \\
\hline Final analysis & 6 months & After 29th May 20 \\
\hline
\end{tabular}

\section{Suplementary Figure 1 - Patient assessment schedule}

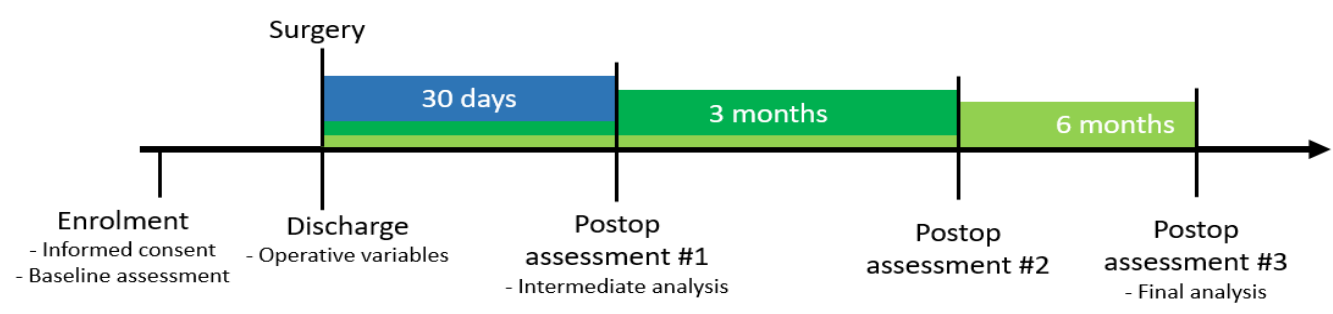


medRxiv preprint doi: https://doi.org/10.1101/2020.12.19.20247585; this version posted December 24, 2020. The copyright holder for this preprint (which was not certified by peer review) is the author/funder, who has granted medRxiv a license to display the preprint in perpetuity.

\title{
Portuguese Inguinal Hernia Cohort Study
}

\author{
Authorship \\ Local leads \\ JS Pimenta, M Romano, AM Cinza, I Miguel, AR Martins, G Fialho, M Reia, FC Borges, CF \\ Monteiro, AC Soares, P Sousa, S Frade, L Matos, JM Carvas, SF Martins, X Sousa, C \\ Rodrigues, JR Carvalho, IC Gil, L Castro, N Rombo, AC Quintela, HM Ribeiro, R Parreira, P \\ Santos, F Caires, A Torre, SC Rodrigues, AH Guimarães, MF Carvalho, MA Pimenta, DC \\ Santos, CF Ramos
}

\section{Steering Committee}

JF Simoes, JM Azevedo, AA Joao, M Peyroteo, B Vieira, M Cunha, N Gonçalves, J Costa, AS Soares (corresponding author) 